\title{
THE RELATIONSHIP BETWEEN COMPETITIVE POSITION AND EFFICIENCY IN THE INDONESIAN-BANKING SECTOR: A PANEL DATA ANALYSIS
}

\author{
Aruddy $^{* 1}$, Noer Azam Achsani**), Hari Wijayanto***), and Bagus Sartono***) \\ *) PT Bank Muamalat Indonesia Tbk \\ Jl. Prof Dr Satrio, Kav. 18, Kuningan Timur, Setiabudi, Jakarta Selatan 12940 \\ ${ }^{* *)}$ School of Business, Bogor Agricultural University \\ Jl. Raya Pajajaran, Bogor 16151 \\ ${ }^{* * *}$ Department of Statistics, Faculty of Mathematics and Natural Sciences, Bogor Agricultural University \\ Jl. Meranti Wing 22 Level 4, Kampus IPB Darmaga, Bogor 16680
}

\begin{abstract}
Analysis on the relationship between competitive position and efficiency with the focus on the Indonesian commercial banks is still very rare. On the other hand, the commercial banks contains banks have systemic impact when they have troubles. The objective of this analysis is to examine the direction of the relationship between competitive position and efficiency which has managerial and policy implications for the parties concerned. The relationship was evaluated using Granger-causality test, where previous studies for Indonesian banking sector did not use this test. The quarterly financial data of each bank sample, balanced sheet and profit/loss statement, were used to calculate the efficiency score and Lerner index. The data were taken from the website of Otoritas Jasa Keuangan (OJK). Lerner index was used as an indicator for competitive position of banks, and higher index means a stronger competitive position. A score calculated by data envelopment analysis (DEA) method is a measure for bank efficiency. Dynamic model is estimated by generalized method of moment (GMM) to address endogeneity and heteroscedasticity issues. The study found that there is a significant one-way positive relationship between efficiency and competitive position, and the causality runs from efficiency to competitive position. The policy implication in this finding is that regulators should avoid implementing a regulation, which is counterproductive in strengthening bank's ability to compete in the market.
\end{abstract}

Keywords: competitive position, DEA, efficiency, Granger-causality, pricing power

\begin{abstract}
Abstrak: Analisis hubungan antara posisi kompetitif dan efisiensi pada bank-bank komersial di Indonesia masih sangat jarang. Di sisi lain, kelompok bank komersial memuat bank-bank yang memiliki dampak sistemik ketika bermasalah. Tujuan analisis ini adalah menguji arah hubungan antara posisi kompetitif dan efisiensi yang memiliki implikasi manajerial dan kebijakan bagi pihak-pihak yang berkepentingan. Hubungan antara posisi kompetitif dan efisiensi dievaluasi menggunakan uji kausalitas Granger. dimana studi sebelumnya untuk sektor perbankan Indonesia tidak menggunakan uji ini. Data keuangan kuartalan setiap bank sampel berupa neraca dan laporan laba/rugi digunakan untuk menghitung skor efisiensi dan indeks Lerner. Data diambil dari situs Otoritas Jasa Keuangan (OJK). Indeks Lerner digunakan sebagai indikator untuk posisi kompetitif suatu bank, indeks yang lebih tinggi berarti posisi kompetitif yang lebih kuat. Skor yang dihitung menggunakan data envelopment analysis (DEA) merupakan ukuran untuk efisiensi bank. Model dinamis diestimasi dengan metode generalized method of moments (GMM) dalam rangka mengatasi masalah endogenitas dan heteroskedastisitas. Studi ini menemukan bahwa ada hubungan positif satu arah yang signifikan antara efisiensi dan posisi kompetitif, kausalitas bergerak dari arah efisiensi ke posisi kompetitif. Implikasi kebijakan atas temuan ini adalah regulator harus menghindari penerapan peraturan yang kontraproduktif dalam memperkuat kemampuan bank untuk bersaing di pasar.
\end{abstract}

Kata kunci: posisi kompetitif, DEA, efisiensi, kausalitas Granger, pricing power

\footnotetext{
${ }^{1}$ Corresponding author:

Email: aruddy2006@gmail.com
} 


\section{INTRODUCTION}

In general, competitive position is considered a positive force for any firms including a bank. A bank with strong competitive position is supposed to improve its efficiency continually, and it should be more innovative and can compete internationally. To promote competitive position, banking regulators design and implement many regulations. For instance, Indonesian-banking regulators implemented a consolidation policy to address any issues in the sector, which causes banking sector to be severely impacted by Asian financial crisis in 1997/1998. The policy has provided good results in strengthening the fundamental of the banks, which is needed to sustain their ability to build competitive position.

A bank with a good competitive position is expected to have good financial performance because it has an ability to operate in an efficient manner. Previous researches evaluated the impact of competitive position in the context of market structure, where the measure of competitive position is an indirect measure such as concentration ratio(CR) or Herfindahl-Hirschman Index (HHI). If a market is more concentrated, firms with higher market shares will have an ability to influence the market for their own benefits; thus, they have a good financial performance. In their development, researches on the financial performance of a bank have shifted to a context rather than market structure, by employing a direct measure in measuring a bank's competitive position such as Lerner index, Boone indicator, PanzarRosse $\mathrm{H}$-statistic etc. In another point of view, financial performance is not directly determined by stronger competitive position but efficiency. Efficient banks have superiority in managing their operation than inefficient banks. Efficiency is generally interpreted as a cost efficiency. Efficient banks will expense less costs so that they have wide profit margin spread, and at the end they earn higher profit rate and eventually their competitive position becomes stronger (Demsetz, 1973; Berger, 1995). There is a belief among academicians, regulators and practitioners that competitive position and efficiency have a form of relationship.

Previous researches found mixed results on the relationship between competitive position and efficiency in the banking industry. For example, Homma et al. (2014) found competitive position has a negative relationship with efficiency for large banks in Japan, Coccorese and Pellecchia (2010), and Koetter and Vins (2008) found similar result for Italian and German banking industries. Meanwhile, Park and Weber (2006) indicated that bank efficiency has a positive relationship with competitive position in Korean. Banking sectors in Latin America region firmly rejected negative relationship between competitive position and efficiency (Williams, 2012) and supported the positive relationship (Chortareas et al. 2011). In particular, for Indonesian banking sector, still only a few researches conducted on efficiency-competitive position relationship. Sastrosuwito and Suzuki (2012) studied Indonesian banking sector over period 2001-2008 and showed that the level of competition measured by Panzar-Rosse H-statistic is found to increase efficiency. Viverita (2014) investigated the relationship between market power and cost efficiency in the Indonesian banking sector over period 20022011, and found a positive relationship. However, Thi My Phan, Daly and Akhter (2016) found negative competitive position-efficiency relationship in the Indonesian banking industry.

In this paper, the relationship between competitive position and efficiency in the Indonesian-banking sector would be analyzed, and the focus was on a specific group of banks that drive the industry since banks control market shares. We hypothesized that efficiency drives competitive position; conversely, competitive position drives efficiency. This means that a bank with a higher level of efficiency will have a better competitive position; conversely, a bank with a better competitive position will have a higher level of efficiency. Efficiency can be interpreted as cost efficiency, so a bank with a high level of efficiency will have a better cost structure compared to other similar banks in term of size. Due to better cost structure, an efficient bank will enjoy wider price-marginal cost spread; in other words, it has larger Lerner index or better competitive position. In another viewpoint, a bank with a better competitive position will have a better negotiating position on sources of input factors and can obtain good input factors at prices more profitable for the bank. Because the bank can have lower prices, it will have a better cost structure for its production process or be more efficient.

Different from the previous studies, our analysis was performed by estimating a panel data dynamic model, so that the model will include lagged dependent variable and implement the GMM to estimate the model because the method will produce consistent estimators even though there is a correlation between explanatory 
variable and error term. We employed DEA to measure efficiency and Lerner index to measure competitive position calculated using bank level data. The Grangercausality analysis showed that efficiency has a positive relationship with competitive position but not the other way round. This means that behavior of a bank to improve its efficiency is intended to enlarge pricing power or widen the spread between product price and marginal cost.

\section{METHODS}

The sample used in this study consisted of the data from the 4 state-owned banks and 24 private-owned foreign exchange commercial banks, and the quarterly unconsolidated financial data over the period of 20022016 were also used. The data were retrieved from OJK website. All banks in the sample accounted for around $90.8 \%$ total assets of foreign exchange banks December 2016. The unconsolidated financial data were used because not all banks in the samples have affiliated companies, and the study focused on the efficiency level of banking activities only. These banks are highly important because in addition to having majority in asset shares, some banks have the potential to be categorized as domestic- systematically important bank (D-SIB).

Three steps should be performed in testing the relationship between competitive position and efficiency. The first step is calculating the Lerner index (Fu et al. 2015). Because the marginal cost data required to calculate the index were not available in the financial reports, the estimated data should be used. The estimated data were derived from cost function with the following specification:

$$
\begin{aligned}
\operatorname{lnCost}_{\mathrm{it}}= & \beta_{0}+\beta_{1} \ln \mathrm{Q}_{\mathrm{it}}+\frac{\beta_{2}}{2} \ln \mathrm{Q}_{\mathrm{it}}^{2}+\sum_{\mathrm{k}=1}^{3} \gamma_{\mathrm{kt}} \ln \mathrm{W}_{\mathrm{kit}} \\
& +\sum_{\mathrm{k}=1}^{3} \varphi_{\mathrm{k}} \ln \mathrm{Q}_{\mathrm{it}} \ln \mathrm{W}_{\mathrm{kit}} \\
& +\sum_{\mathrm{k}-1}^{3} \sum_{\mathrm{j}=1}^{3} \ln \mathrm{W}_{\mathrm{kit}} \ln \mathrm{W}_{\mathrm{jit}}+\varepsilon_{\mathrm{it}}
\end{aligned}
$$

Cost is the total cost (operating cost + non-operating cost), Q is the value of bank product (total assets or total earning assets as a proxy), $\mathrm{W}$ is input factor (personnel, public fund, and physical assets). The $\beta \mathrm{s}, \gamma$, $\varphi$ are parameters to be estimated and $\varepsilon$ is a disturbance term. The derivation of the above equation will produce marginal cost function as follows:

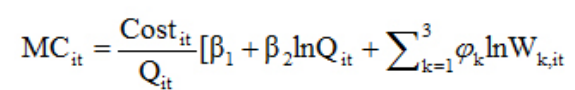

The second step is calculating efficiency score using DEA. DEA is a mathematical approach to construct production frontier from actual data. DEA utilizes linear programming (LP) to select firms that are identified as the most efficient firms and construct a piece-wise linear convex curve that bounds or envelopes other least efficient firms (Castellanos et al. 2016). In this study, the LP problem for DEA consists of two outputs and three inputs. The outputs are loan and securities, and the inputs are public funds, personnel and physical capital. Production approach and variable of returns to scale (VRS) are the characteristics of our DEA. The specification of the LP is:

$\min _{\theta, \lambda} \quad \theta$

subject to: $\theta \mathrm{xi}-\mathrm{X} \lambda \geq 0$

$$
\begin{aligned}
\text { yi }-\mathrm{Y} \lambda & \geq 0 \\
\lambda & \geq 0
\end{aligned}
$$

The last step is estimating a model that exhibits the functional form of the relationship between competitive position and efficiency. The following autoregressivedistributed linear model (Casu and Girardone, 2009) was used to uncover the relationship between competitive position and efficiency:

$$
\mathrm{Y}_{\mathrm{it}}=\alpha_{1} \mathrm{y}_{\mathrm{i}, \mathrm{t}-1}+\alpha_{2} \mathrm{y}_{\mathrm{i}, \mathrm{t}-2}+\beta_{1} \mathrm{x}_{\mathrm{i}, \mathrm{t}-1}+\beta \mathrm{x}_{\mathrm{i}, \mathrm{t}-1}+\theta_{\mathrm{t}}+\eta_{\mathrm{i}}+\mathrm{v}_{\mathrm{it}}
$$

The yit and xit are represented alternatively by a measure of competitive position (the Lerner index) and bank efficiency (the DEA score). The $\alpha \mathrm{j}$ and $\beta \mathrm{j}$ are parameters to be estimated, $\theta \mathrm{t}$ is a common time effect, $\eta \mathrm{i}$ is an individual bank specific effect and vit is a disturbance term.

We employed the difference of Generalized Method of Moments (DIF-GMM) estimator (Arellano and Bond 1991, BiØrn 2017) for the coefficients in the above equation where the lagged level of the regressors is instruments for the equation in the first difference. We also used the GMM (SYS-GMM) estimator system developed by Arellano and Bover (1995); Blundell, and Bond (1998), and this system was designed to overcome some of the limitations of the DIF-GMM; for example, the weak instrument for first difference due to the series is highly persistent. In addition to AR (2) model specified in the above model, we also estimated AR (4) model. In the AR (2), the joint null $\beta 1=\beta 2=0$ 
is interpreted as a panel data test for Granger causality, while the joint null for AR (4) is $\beta 1=\beta 2=\beta 3=\beta 4=$ 0 . The sign of the causal relationship is determined by the sum of the jointly significant coefficients. A positive sign implies that the causal relationship is also positive or vice versa. This means that an increase in $\mathrm{x}$ in the past increases the $y$ in the present. The estimated models are checked for the stability over time or "longrun effect" (Casu and Girardone, 2009) of the x over the $y$ by testing the restriction $\beta 1+\beta 2=0$ in case of AR (2) model and $\beta 1+\beta 2+\beta 3+\beta 4=0$ in case of AR (4) model. If the restriction is rejected, there is evidence of a long-run effect of $\mathrm{x}$ on $\mathrm{y}$; in other words, $\mathrm{y}$ will depend on the change in $\mathrm{x}$ rather than on its level.

\section{RESULTS}

\section{A one-way Relationship from Efficiency to Competitive Position}

Table 1 presents estimated coefficients for the dynamic model. The term Lag: 2 and Lag: 4 means the coefficients are for AR(2) model and AR(4) model respectively. First, look at estimated AR(2) model. Estimated model with Lerner as dependent variable by DIF-GMM shows that the coefficient of Lerner at t- 1 is 0.6373 and statistically significant at $1 \%$ test level, while that at $\mathrm{t}-2$ is 0.0074 but not statistically significant. It means that previous quarter competitive position provides a significant effect on the current position, in addition to effect of other factors that have causation with the competitive position. The coefficient of efficiency at $\mathrm{t}-1$ is -0.0851 and statistically significant at $5 \%$ test level, while that at $\mathrm{t}-2$ is 0.1489 and statistically significant at $1 \%$. Since coefficients of lagged efficiency are statistically significant as confirmed by Wald-test that rejected $\beta 1=\beta 2=0$, information on previous level of efficiency provides significant information on the current competitive position or in other words, efficiency is a Granger-cause for competitive position. Efficiency at t-1 has a significant negative relationship with current competitive position, indicating that in the short term, banks do not exploit efficiency improvement to widen the spread between price and marginal cost. This condition indicates that it is very likely the cost savings proceeded is allocated for other purposes such as improving quality of facilities and infrastructure to increase the number of customers and volume of banking transactions instead of offering lower interest rate for loan products or higher interest rate for saving products. However, efficiency improvement at $\mathrm{t}-2$ has a significant positive relationship with current level of efficiency, meaning that in the longer term, banks exploit efficiency improvement to widen the spread between product price and marginal cost in order to earn higher profit.

Total effect of efficiency on competitive position can be seen from sum of coefficients of lagged efficiency. If not all individual coefficients of lagged efficiency have the same sign, then total effect is a net effect. The sum of coefficients of lagged efficiency is 0.0638 and statistically significant at $10 \%$ test level, indicating that the net effects of previous levels of efficiency had a positive relationship with current competitive position; therefore, efficiency improvement from the previous periods will provide information why current competitive position is stronger.

Secondly, look at the DIF-GMM estimator for the AR (4) model. The last quarter competitive position has a significant effect on current position as indicated by the coefficient of Lerner at $\mathrm{t}-1$ of 0.5124 , and it is statistically significant at $1 \%$ test level. While other coefficients at $\mathrm{t}-2, \mathrm{t}-3$ and $\mathrm{t}-4$ are not significant, they do not significantly affect current competitive position. The effects of efficiency during the past four quarters on the current competitive position are quite significant. The coefficients of lagged efficiency are -0.0778 at $\mathrm{t}-1,0.1625$ at $\mathrm{t}-2,-0.0845$ at $\mathrm{t}-3$ and 0.0656 at $\mathrm{t}-4$. The individual coefficient shows that previous efficiency levels have significant effects on competitive position at least at $10 \%$ test level; however, the total effect of efficiency is not significant. This is because sum of coefficients of lagged efficiency or the net effect of efficiency on the competitive position is 0.0658 , and the Wald test did not reject the hypothesis whose sum or net effect is 0 . We postpone to conclude that total effects of the past four quarters of the efficiency level is not significant under the DIF-GMM estimator until we evaluate the same issue by applying SYS-GMM as method of estimation.

The SYS-GMM estimator for AR (2) model is presented in Table 2. Firstly, look at the model with Lerner as the dependent variable. The Lerner index at $\mathrm{t}-1$ has a significant positive impact on current competitive position with the estimated coefficient of 0.6419 and significance at $1 \%$ test level, and the coefficient at time $\mathrm{t}-2$ is -0.0090 , and it is not statistically significant. Furthermore, each coefficient of lagged efficiency 
has the same sign as the estimated coefficient by the DIF-GMM. The coefficient of lagged efficiency at time $\mathrm{t}-1$ is -0.1068 and at time $\mathrm{t}-2$ is 0.1826 , and both coefficients are statistically significant at $1 \%$ test level. It means the information on the previous level of efficiency provides significant information on the current competitive position or in other words, efficiency is a Granger-cause for competitive position. The net effect of efficiency is 0.0758 , slightly larger than the calculation by the DIF-GMM estimator, and the net effect is statistically significant at $1 \%$ test level. The level of significance under SYS-GMM estimator is higher than that under DIF-GMM estimator.
Next, let us evaluate the estimated AR (4) model by the SYS-GMM estimator. All coefficients of lagged Lerner have the same sign as the DIF-GMM estimator but different sign in statistical significance. The coefficient of lagged Lerner at time t-1 is 0.5276 and statistically significant at $1 \%$ test level (the same as the DIF-GMM estimator), while at $\mathrm{t}-2$ and $\mathrm{t}-3$ the coefficients are -0.0253 and 0.0269 respectively. Both coefficients are statistically significant at $10 \%$ test level (however, DIFGMM estimators are not significant), and the coefficient at $\mathrm{t}-4$ is 0.009 and is not statistically significant (the same as DIF-GMM estimator). This means that in the past periods, levels of competition have significant impact on strengthening current competitive position, but the increase is not monotonic because not all coefficients of past period levels of competition are positive.

Table 1. Granger-Causality between competition and efficiency, DIF-GMM

\begin{tabular}{|c|c|c|c|}
\hline \multirow{2}{*}{ Dependent and Independent Variable } & \multirow{2}{*}{ Coefficients and Tests } & \multirow{2}{*}{$\begin{array}{l}\text { Lag: } 2 \\
\text { DIF-GMM }\end{array}$} & \multirow{2}{*}{$\begin{array}{l}\text { Lag: } 4 \\
\text { DIF-GMM }\end{array}$} \\
\hline & & & \\
\hline \multirow[b]{2}{*}{ Dependent : } & Lerner t-1 & $0.6373 * * *$ & $0.5124 * * *$ \\
\hline & Lerner $\mathrm{t}-2$ & 0.0074 & -0.0018 \\
\hline \multirow{11}{*}{$\mathrm{x}=$ Efficiency Score } & Lerner t-3 & & 0.0178 \\
\hline & Lerner t-4 & & 0.0003 \\
\hline & Efficiency t-1 & $-0.0851 * *$ & $-0.0778 * *$ \\
\hline & Efficiency t-2 & $0.1489 * * *$ & $0.1625 * * *$ \\
\hline & Efficiency t-3 & & $-0.0845^{*}$ \\
\hline & Efficiency t-4 & & $0.0656 * * *$ \\
\hline & $\sum$ Efficiency & 0.0638 & 0.0658 \\
\hline & All $\beta \mathrm{s}=0$, prob $>$ Chi-Square & 0.0005 & 0.0001 \\
\hline & $\mathrm{AB}$ test order $=1, \mathrm{p}$-value & 0.0015 & 0.0002 \\
\hline & $\mathrm{AB}$ test order $=2, \mathrm{p}$-value & 0.8075 & 0.2505 \\
\hline & Sum of $\beta s=0, p$-value & 0.0709 & 0.1307 \\
\hline \multirow[t]{3}{*}{ Dependent : } & Efficiency t-1 & $0.5783^{* * *}$ & $0.5447 * * *$ \\
\hline & Efficiency t-2 & $0.1597 * * *$ & $0.0886^{* *}$ \\
\hline & Efficiency t-3 & & 0.0380 \\
\hline \multirow[t]{10}{*}{$\mathrm{x}=$ Lerner Index } & Efficiency t-4 & & $0.1384 * * *$ \\
\hline & Lerner t-1 & 0.0182 & 0.0161 \\
\hline & Lerner $\mathrm{t}-2$ & -0.0028 & 0.0113 \\
\hline & Lerner $\mathrm{t}-3$ & & $-0.0253^{*}$ \\
\hline & Lerner t-4 & & -0.0133 \\
\hline & $\sum$ Lerner & 0.0154 & -0.0112 \\
\hline & All $\beta \mathrm{s}=0$, prob $>$ Chi-Square & 0.5787 & 0.2825 \\
\hline & $\mathrm{AB}$ test order $=1, \mathrm{p}$-value & 0.0001 & 0.0001 \\
\hline & $\mathrm{AB}$ test order $=2, \mathrm{p}$-value & 0.0262 & 0.1060 \\
\hline & Sum of $\beta s=0, p$-value & 0.4006 & 0.5837 \\
\hline
\end{tabular}

Note: GMM estimator with robust variance. $*, * *, * * *$ denote statistically significant at $10 \%, 5 \%$ or $1 \%$. Arellano-Bond (AB) tests for autocorrelation $\operatorname{AR}(1)$ and $\operatorname{AR}(2)$ have a null hypothesis of no autocorrelation. All $\beta \mathrm{s}=0$ means $\beta 1=\beta 2=0$ or $\beta 1=$ $\beta 2=\beta 3=\beta 4=0$. Sum of $\beta \mathrm{s}=0$ means $\beta 1+\beta 2=0$ or $\beta 1+\beta 2+\beta 3+\beta 4=0$. 
The pattern effect of efficiency on competitive position with the SYS-GMM estimator is similar to DIF-GMM estimator. The similarity of the pattern is indicated by sign and significance of each coefficient of lagged efficiency. All signs of coefficient of lagged efficiency are the same whether estimated by the SYS-GMM or by the DIF-GMM so that the pattern effect of efficiency on competitive position is similar. However, there is a slight difference in the significance of the coefficient of efficiency at t-3 that is -0.856 and not statistically significant for the SYS-GMM, while it is -0.845 and statistically significant at $10 \%$ for the DIF-GMM. The material difference lies on the significance of net effect afforded by efficiency, where Wald test rejected the hypothesis that all coefficients of lagged efficiency are 0 , while the sum of coefficients of lagged efficiency is 0.1036 , and the sum is statistically significant at $1 \%$ test level. Based on the facts from estimated AR (2) and AR (4) model by applying the SYS-GMM as method of estimation, we can draw a conclusion that there is a significant positive relationship between efficiency and competitive position. The positive relationship means that efficiency improvement during the past periods will increase the pricing power, and banks will have better competitive position.

\section{A one-way Relationship of Competitive Position to Efficiency}

Let us look at the results for model with efficiency as the dependent variable and the DIF-GMM used as the method of estimation as presented in Table 1. When we regress efficiency on the lagged efficiency and the lagged Lerner, it means that we intend to evaluate whether competitive position is a Granger-cause for efficiency. First, estimated AR(2) model shows that the coefficients of level of efficiency at time t- 1 and $t-2$ are 0.5783 and 0.1597 respectively, and both coefficients are statistically significant at $1 \%$ test level, indicating that level of efficiency in the previous two quarters have a significant impact on its current level. We argue that bank managers pay more attention to what level of efficiency they have already achieved, and they then continuously make efforts to maintain the efficiency level or even increase it whenever possible. Efficiency is an indicator targeted in the annual bank business plan; thus, it is not surprising that bank managers pay more attention on their efficiency level. Therefore, the efficiency level of the past periods will have a significant impact on achieving current level of efficiency as confirmed by the estimated model.
The estimatedAR(4) model shows similar results to AR(2) model in which coefficients of level of efficiency for the past two quarters had significant effects on current level of efficiency. The coefficients of efficiency at t- 1 and $t-2$ are 0.5447 and 0.0886 respectively, and both coefficients are positive and statistically significant at least at $5 \%$ test level. In addition, level of efficiency at t-3 and t- 4 also have positive signs although only coefficients at $\mathrm{t}-4$ is statistically significant at $1 \%$ test level. The results of estimated AR(4) model confirm the indication provided by estimated AR(2) model in which bank managers pay more attention to what level of efficiency they have already achieved. In addition, they should continuously make any efforts to maintain the efficiency level or even increase it whenever possible so that the efficiency level of the previous periods will have significant impacts on achieving current level of efficiency.

Moreover, each coefficient of lagged Lerner in estimated AR (2) model is not statistically significant, where the coefficients at time $\mathrm{t}-1$ and time $\mathrm{t}-2$ are 0.0182 and -0.0028 respectively. Wald test did not reject the hypothesis that both coefficients are 0 . The sum of both coefficients is 0.0154 , and Wald test did not reject the hypothesis that the sum of these coefficients is 0 . Based on these facts, we conclude that competitive position is not Granger-cause for level of competition. The same results were also provided by the estimated AR (4) model. The coefficients of lagged Lerner at $t-1$ and $\mathrm{t}-2$ are 0.0161 and 0.0113 respectively, while for time $\mathrm{t}-3$ and $\mathrm{t}-4$, the coefficients are -0.0253 and -0.0133 respectively. Each of four coefficients is not statistically significant, and Wald test did not reject the hypothesis that four coefficients are 0 . The sum of four coefficients is -0.0112 , and Wald test did not reject the hypothesis that the sum of these coefficients is 0 . Based on these facts, we conclude that competitive position is not Grangercause for level of efficiency, indicating that whatever previous competitive position or pricing power a bank has does not provide any information on the current level of efficiency achievement.

Estimated models by applying the SYS-GMM as the method of estimation in Table 2 show that for estimated AR (2) model, both coefficients of lagged efficiency are statistically significant at $1 \%$ test level, and the coefficient at $\mathrm{t}-1$ is 0.6552 and at $\mathrm{t}-2$ is 0.2501 . This means that level of efficiency at the two previous quarters will significantly affect the current efficiency improvement. However, one coefficient of lagged Lerner is statistically significant but the other one is not significant. The coefficient of Lerner 
at $\mathrm{t}-1$ is 0.0441 and statistically significant at 5\% test level, while coefficient of Lerner at t-2 is -0.0139 . Net effect of competitive position is 0.0301 , and this net effect is not statistically significant at 5\% test level. Therefore, there is no solid reason to conclude that competitive position has a strong relationship with the efficiency, even though the coefficient of the last quarter competitive position is statistically significant at 5\% test level. The conclusion of AR (2) model estimated by the SYS-GMM confirms the conclusion of the same model but estimated by the DIF-GMM.

For the estimated AR (4) model, all coefficients of lagged efficiency are statistically significant at least at $5 \%$ statistical test level. The signs of the coefficients are the same as showed by DIF-GMM estimator. The coefficients of the past two quarters and the previous fourth quarter are significant at 1\% test level, while coefficient of the previous third quarter is significant at 5\% level. This means that level of efficiency in the past four quarters will significantly affect the current efficiency improvement, and it confirms what the same model estimated by the DIF-GMM has showed. Meanwhile, none of coefficients of lagged Lerner is significant, where the last quarter of Lerner has positive coefficient and the rests are negative. The sum of four coefficients of lagged Lerner is -0.0100 and Wald test procedure did not reject that the sum is 0 ; hence, there is no indication that previous competitive position has any significant effects on the efficiency currently achieved. These facts confirm the facts provided by the same model estimated by the DIF-GMM.

Table 2. Granger-Causality between competition and efficiency, SYS-GMM

\begin{tabular}{|c|c|c|c|c|}
\hline \multirow{2}{*}{\multicolumn{2}{|c|}{ Dependent and Independent Variable }} & \multirow{2}{*}{ Coefficients and Tests } & \multirow{2}{*}{$\begin{array}{c}\text { Lag: } 2 \\
\text { DIF-GMM }\end{array}$} & \multirow{2}{*}{$\begin{array}{c}\text { Lag: } 4 \\
\text { DIF-GMM }\end{array}$} \\
\hline & & & & \\
\hline \multirow{3}{*}{ Dependent : } & & Lerner t-1 & $0.6419 * * *$ & $0.5276^{* * *}$ \\
\hline & & Lerner $\mathrm{t}-2$ & -0.0090 & $-0.0253^{*}$ \\
\hline & $\mathrm{y}=$ Lerner Index & Lerner t-3 & & $0.0269 *$ \\
\hline \multirow[t]{10}{*}{ Independent: } & & Lerner t-4 & & 0.0009 \\
\hline & $\mathrm{x}=$ Efficiency Score & Efficiency t-1 & $-0.1068 * * *$ & $-0.0788 * * *$ \\
\hline & & Efficiency t-2 & $0.1826 * * *$ & $0.2017 * * *$ \\
\hline & & Efficiency t-3 & & -0.0856 \\
\hline & & Efficiency t-4 & & $0.0663 *$ \\
\hline & & $\sum$ Efficiency & 0.0758 & 0.1036 \\
\hline & & All $\beta \mathrm{s}=0$, prob $>$ Chi-Square & 0.0000 & 0.0000 \\
\hline & & AB test order $=1, p$-value & 0.0007 & 0.0001 \\
\hline & & $\mathrm{AB}$ test order $=2, \mathrm{p}$-value & 0.6906 & 0.0679 \\
\hline & & Sum of $\beta s=0, p$-value & 0.0000 & 0.0000 \\
\hline \multirow[t]{2}{*}{ Dependent : } & & Efficiency t-1 & $0.6552 * * *$ & $0.5743 * * *$ \\
\hline & $\mathrm{y}=$ Efficiency Score & Efficiency t-2 & $0.2501 * * *$ & $0.1022 * * *$ \\
\hline \multirow[t]{11}{*}{ Independent: } & & Efficiency t-3 & & $0.0812 * *$ \\
\hline & $\mathrm{x}=$ Lerner Index & Efficiency t-4 & & $0.1725^{* * *}$ \\
\hline & & Lerner t-1 & $0.0441 * *$ & 0.0292 \\
\hline & & Lerner t-2 & -0.0139 & -0.0022 \\
\hline & & Lerner t-3 & & -0.0188 \\
\hline & & Lerner t-4 & & -0.0183 \\
\hline & & $\sum$ Lerner & 0.0301 & -0.0100 \\
\hline & & All $\beta \mathrm{s}=0$, prob $>$ Chi-Square & 0.1141 & 0.2126 \\
\hline & & AB test order $=1, p$-value & 0.0001 & 0.0001 \\
\hline & & AB test order $=2, p$-value & 0.0025 & 0.8861 \\
\hline & & Sum of $\beta s=0, p$-value & 0.0986 & 0.5715 \\
\hline
\end{tabular}

Note: GMM estimator with robust variance. *, **, *** denote statistically significant at 10\%, 5\% or 1\%. Arellano-Bond (AB) tests for autocorrelation $\operatorname{AR}(1)$ and $\operatorname{AR}(2)$ have a null hypothesis of no autocorrelation. All $\beta \mathrm{s}=0$ means $\beta 1=\beta 2=0$ or $\beta 1=$ $\beta 2=\beta 3=\beta 4=0$. Sum of $\beta \mathrm{s}=0$ means $\beta 1+\beta 2=0$ or $\beta 1+\beta 2+\beta 3+\beta 4=0$. 


\section{Model Misspecification Test}

We apply Arellano-Bond (AB) procedure to test whether the estimated models are valid. Based on this procedure, no model misspecification will be confirmed if the disturbance terms are correlated under autoregressive order 1 pattern or AR (1), but they are independent under autoregressive order 2 pattern or AR (2). The 5\% statistical test level will be used to conclude the test result. For models with Lerner as the dependent variable, the test on the AR (2) model shows that the models are valid for both estimators in which the $\mathrm{p}$-value for AR(1) disturbance terms is less than 5\% and the p-value for $\mathrm{AR}(2)$ disturbance terms is larger than 5\%. As for AR (4) models, the test result also shows that the models are valid for both estimators. The general conclusion also applies for the test results when efficiency is set as a dependent variable.

Our findings above are in line with Viverita (2014) and Sastrosuwito and Suzuki (2012); however, they are different from the findings by Thi My Phan, Daly and Akhter (2016) who found that in the Indonesian banking system, there is a negative relationship between competitive position or market power with efficiency. Coccorese and Pellecchia (2010) found a negative relationship between competition and efficiency for Italian banking case, and Casu and Girardone (2009) found negative Granger-causality from efficiency to competition and weak positive Granger-causality from competition to efficiency in 5 EU countries. In addition, Schaeck and Cihak (2008) found two-way negative Granger-causality between profit efficiency and competition in $10 \mathrm{EU}$ countries, and Weill (2004) found negative relationship between competition and efficiency in $12 \mathrm{EU}$ countries.

\section{Managerial Implications}

Bank managers must continuously evaluate their bank efficiency level and improve their quality of managerial decisions. If their bank is inefficient and no significant corrective actions take place, their financial performance will worsen; as a result, their customers may switch to use products and services offered by other banks. In pursuing efficiency improvement, bank managers must review their infrastructures, policies, products and services offered to customers, market segments served and profitability of their customers. Board of commissioners should ensure bank managers to have a clear strategic plan for sustainable efficiency achievement.

Regulators should monitor level of efficiency for each bank particularly for banks that are categorized as D-SIB bank. It may be necessary to establish regulations on sustained efficiency improvements. A regulation on the efficiency aims to require banks to have a clear annual action plan in an effort to improve their efficiency. There should also be established rules on minimum efficiency limit and maximum reduction in efficiency level. If banks breach the limit, the regulators must take regulatory actions on those banks to prevent the deterioration of their performance due to inefficiency.

\section{CONCLUSIONS AND RECOMMENDATIONS}

\section{Conclusions}

This paper discusses the relationship between efficiency and competitive position. Granger causality analysis will show the pattern of the relationship between efficiency and competitive position. Since we constructed the dynamic model, GMM estimator will estimate such model and Arellano-Bond test procedure evaluates the misspecification of constructed models. Total effects of efficiency on competitive position or vice versa are the main concern for this Granger-causality test; therefore, the total effects are net effects, which reflect a longterm effect.

Granger-causality test showed that level of efficiency during past periods helps predict stronger competitive position, but this competitive position does not help predict level of efficiency so that there is a one-way relationship running from efficiency to competitive position, and the relationship is positive. It means that if banks keep continuing to improve their efficiency level, they will get stronger competitive position or bigger pricing power. Bigger pricing power can be converted into a larger market share by allocating profits to improve quality of production facilities and infrastructure to attract consumers or by lowering earning assets product price to increase volume of banking transactions. 


\section{Recommendations}

In relation to the empirical result of this study, issues that need to be studied deeply in future include differences in behavior among banks that have high, moderate and low pricing power or competitive position. Secondly, to find out whether there is a tendency for banks to continue maintaining the size of their pricing power although cost of funds continues declining with the improved economic conditions. Profit maximizing is one of the objectives of banks; therefore, decisions to maintain or enlarge the pricing power are rational in pursuing the objective that is how each bank takes its decision and what considerations it has. Furthermore, improvement in economic conditions has led to a decrease in cost of funds, reduction in total costs borne by banks, and this certainly provides fuel for increasing pricing power. The question is whether banks let their pricing power continue to increase or targeted at a certain level.

\section{REFERENCES}

Arellano M, Bond S. 1991. Some tests of specification for panel data: Monte carlo evidence and an application to employment equations. Review of economic studies 58: 277-297. https://doi. org/10.2307/2297968.

Arellano M, Bover O. 1995. Another look at the instrumental variables estimation of error components models. Journal of Econometrics 68: 29-51.

Berger AN. 1995. The Profit-Structure relationship in banking: Tests of market-power and efficient structure hypothesis. Journal of Money, Credit and Banking 27 (2): 404-431. https://doi. org/10.2307/2077876.

BiØrn E. 2017. Econometrics of panel data: Methods and Application. Oxford University Press.

Blundell R, Bond SR. 1998. Initial conditions and moment restrictions in dynamic panel data models. Journal of Econometrics 87: 115-143.

Casu B, Girardone C. 2009. Testing the relationship between competition and efficiency in banking: A panel data analysis. Economics Letters 105: 134-137.

Castellanos SG, Del Angel GA, Garza-Garcia JG. 2016. Competition and efficiency in the Mexican banking industry: Theory and Empirical evidence. Palgrave Macmillan.
Chortareas GE, Garza-Garcia JG, Girardone C. 2011. Banking sector performance in Latin America: Market Power versus Efficiency. Review of Development Economics 15 (2): 307-325.

Coccorese P, Pellecchia A. 2010. Testing the "Quiet Life' hypothesis in the Italian banking industry. Economic Notes by Banca Monte dei Paschi di Siena SpA 39 (3): 173-202.

Demsetz H. 1973. Industry structure, market rivalry, and public policy. Journal of Law and Economics 16: $1-9$.

Fu X, Lin Y, Molyneux P. 2015. Bank competition, efficiency and liquidity creation in Asia Pacific. Palgrave Macmillan.

Homma T, Tsutsui Y, Uchida H. 2014. Firm growth and efficiency in the banking industry: a new test of the efficient structure hypothesis. Journal of Banking \& Finance 40: 143-153. https://doi. org/10.1016/j.jbankfin.2013.11.031.

Koetter M, Vins O. 2008. The quite life hypothesis in bank: Evidence from German savings bank. WP Finance \& Accounting 190.

Park KH, Weber WL. 2006. Profitability of Korean banks: Test of market structure versus efficient structure. Journal of Economics and Business 58: 222-239

Sastrosuwito S, Suzuki Y. 2012. The impact of competition on bank efficiency: The evidence from Indonesia. Business and Management Review 2(6): 1-9.

Schaeck K, Cihak M. 2008. How does competition effect efficiency and soundness in banking?: New empirical evidence. ECB Working Paper 932.

Thi My Phan H, Daly K, Akhter S. 2016. Bank efficiency in emerging Asian countries. Research in International Business and Finance 38: 517 530. https://doi.org/10.1016/j.ribaf.2016.07.012.

Viverita. 2014. Cost efficiency and market power: A test of quiet life and related hypothesis in Indonesian banking industry. In: Emrouznejad A., Cabanda E. (eds) Managing Service Productivity. International Series in Operation Research \& Management Science 215.

Weill L. 2004. On the relationship between competition and efficiency in the EU banking sectors. Kredit und Kapital.

Williams J. 2012. Efficiency and market power in Latin America banking. Journal of Financial Stability 8: 263-276. https://doi.org/10.1016/j. jfs.2012.05.001. 